Article

\title{
Korean Experimentation of Knowledge and Technology Transfer to Address Climate Change in Developing Countries
}

\author{
Taewook Huh ${ }^{1, *}$ and Hyung-Ju Kim ${ }^{2}$ \\ 1 Moon Soul Graduate School of Future Strategy, KAIST (Korea Advanced Institute of Science \& Technology), \\ Daejeon 34141, Korea \\ 2 Policy Research Division, Green Technology Center, Seoul 04554, Korea; hjkim@gtck.re.kr \\ * Correspondence: twhuh@kaist.ac.kr; Tel.: +82-2-10-5763-2363
}

Received: 20 March 2018; Accepted: 18 April 2018; Published: 19 April 2018

\begin{abstract}
This paper explores two Korean cases of Knowledge and Technology Transfer (KTT) to address climate change in developing countries. The target technologies were carbon capture and utilization (CCU) in a project in Bantayan Island, Philippines, and waste-to-energy (WTE) technology in Santiago, Dominican Republic. These projects were conducted by the Republic of Korea's Green Technology Center. The study analyses the rationale of KTT ("international environment" and "motives"), its objects (technology types) and activities ("informational contacts", "research activities", "consulting" and "education and training"). It concludes that the KTT efforts of these two case studies can be characterized as "uninformed transfer", given a lack of information on situational factors. In particular, these projects faced cooperation problems between national and local governments in the target countries due to different levels of commitment among different stakeholder groups. In conclusion, this study identifies the implications of an acceptability gap between national and local actors in renewable energy projects of KTT.
\end{abstract}

Keywords: Knowledge and Technology Transfer; carbon captured and utilization; waste-to-energy; uninformed transfer; national acceptability; local acceptability

\section{Introduction}

The urgent need for climate technology transfer and financial assistance from developed countries to developing countries have drawn international attention since the United Nations Framework Convention on Climate Change (UNFCCC) Paris Agreement of December 2015. The effects of climate change around the world are not area-defined issues and therefore require responses and cooperation at domestic and global levels.

The concept of Knowledge and Technology Transfer (KTT) is an umbrella framework of the Paris Agreement. This can be defined as activities or processes aimed at transferring knowledge or technology to help organizations in developing or developed countries to pursue their goals [1-4]. The terms "knowledge" and "technology" share common characteristics and are often used interchangeably. However, as Farley and Sharer [5] and Landry et al. [6] argue, knowledge and technology differ in terms of purpose, degree of codification, and type of storage. In fact, technology can be considered as a sub-category of knowledge.

In this regard, this study tries not to review knowledge transfer or technology transfer separately in a narrow way, focusing on individual sectors and types of them, but instead tries to analyze interconnected environments and contents in the comprehensive context of KKT; for example, focusing on including rationales (motives), objects, activities, and degree and results of KKT $[7,8]$. 
This study aims to explain and analyse the Korean exploration of KTT to address climate change in developing countries. It notes both cases (projects) by the Green Technology Center in South Korea (GTC-K) in the Philippines and the Dominican Republic. GTC-K and its domestic and international partners carried out the projects from June 2014 to May 2016 [9]. The carbon capture and utilization (CCU) project was carried out in Bantayan Island, Cebu, Philippines, and the waste-to-energy (WTE) project was carried out in Santiago city, Dominican Republic. However, after concluding the feasibility study results and Green Climate Fund (GCF) funding proposal, GTC-K finally withdrew from both the CCU and WTE projects without entering the project initiation phase.

This paper approaches these case studies with a qualitative methodology including multiple methods. They were carried out both in the form of traditional face to face meetings via the focus group interviews (FGI) and the individual in-depth interviews with related staff and experts (eight respondents) who were actively involved in both projects. The snowball sampling was used to ask respondents who have already been interviewed to introduce other informants who have relevant information on the research subject. The FGI was conducted with four related staff and experts in October 2017 and the individual in-depth interviews were carried out from November 2017 to January 2018 about the rationale, objects and activities, obstacles, performances, and results of the both projects in light of KKT. In order to preserve respondents' anonymity, this paper uses a numbering system when citing their quotations. This study adopts content and thematic analysis, using the qualitative methodology program, NVIVO 10 that is a qualitative data analysis software supporting qualitative and mixed methods research by helping researchers to organize, analyse and find insights. Through the coding scheme of the thematic analysis, the commonality and the difference of the interview result data were distinguished and the grouping into the umbrella term was performed.

This paper is structured as follows: in Section 2, we discuss the theoretical background of the study and set up the analytical framework based on the literature review. In Section 3, we present the initial findings in relation to the rationale of KTT ("international environment" and "motives"), and in Section 4, we specify the findings regarding the objects (technology types) and activities ("informational contacts", "research activities", "consulting" and "education and training") of KTT. Finally, Section 5 shows the degree and results of KTT that is characterized by "uninformed transfer" reflecting that transfer degree and results of KTT efforts are challenged by a lack of information and also suggests the implications of the social gap between national and local acceptability for such interventions.

\section{Theoretical Background and Analytical Framework}

\subsection{The UNFCCC Technology and Finance Mechanisms}

KTT activities have been facilitated at the global level through the technology and finance mechanisms of the UNFCCC as Figure 1 illustrates. The Technology Executive Committee (TEC) describes "climate technologies" as those that help reduce greenhouse gas emissions, such as renewable energies, and those that help adapt to adverse effects of climate change, such as drought-resistant crop and early warning systems [10]. UNFCCC SCF (Standing Committee on Finance) defines that "climate finance" aims at reducing GHG emissions and maintaining and increasing the resilience of, human and ecological systems to negative climate change impacts [11]. Through their participation in these mechanisms, countries have confirmed the importance of enhancing the development and transfer of climate technologies to developing countries [12,13].

Established in 2010 by the Conference of the Parties (COP) to the UNFCCC, the Technology Mechanism to support countries' efforts to accelerate and enhance action on climate change [12,14], which helps countries to develop and transfer climate technologies to effectively reduce greenhouse gas (GHG) emissions and adapt to the adverse effects of a climate. Technologies play a central role in addressing climate change, by helping to reduce GHG emissions, including through renewable energies such as wind energy, solar power and hydropower. They can also help adapt to the adverse effects of climate change by utilizing drought-resistant crops, extreme weather early warning systems and 
sea walls. There are also "soft" climate technologies, such as energy-efficient practices and knowhow to operate machinery. The two bodies of the UNFCCC Technology Mechanism-the Technology Executive Committee (TEC) and the Climate Technology Centre and Network (CTCN)—work together to enhance action on climate technology. Their complementary functions support developing countries' efforts to address both policy and implementation aspects of climate technology development and transfer. They work to enrich coherence and synergy in the delivery of climate technology support and to respond effectively to the needs of countries $[12,15]$.

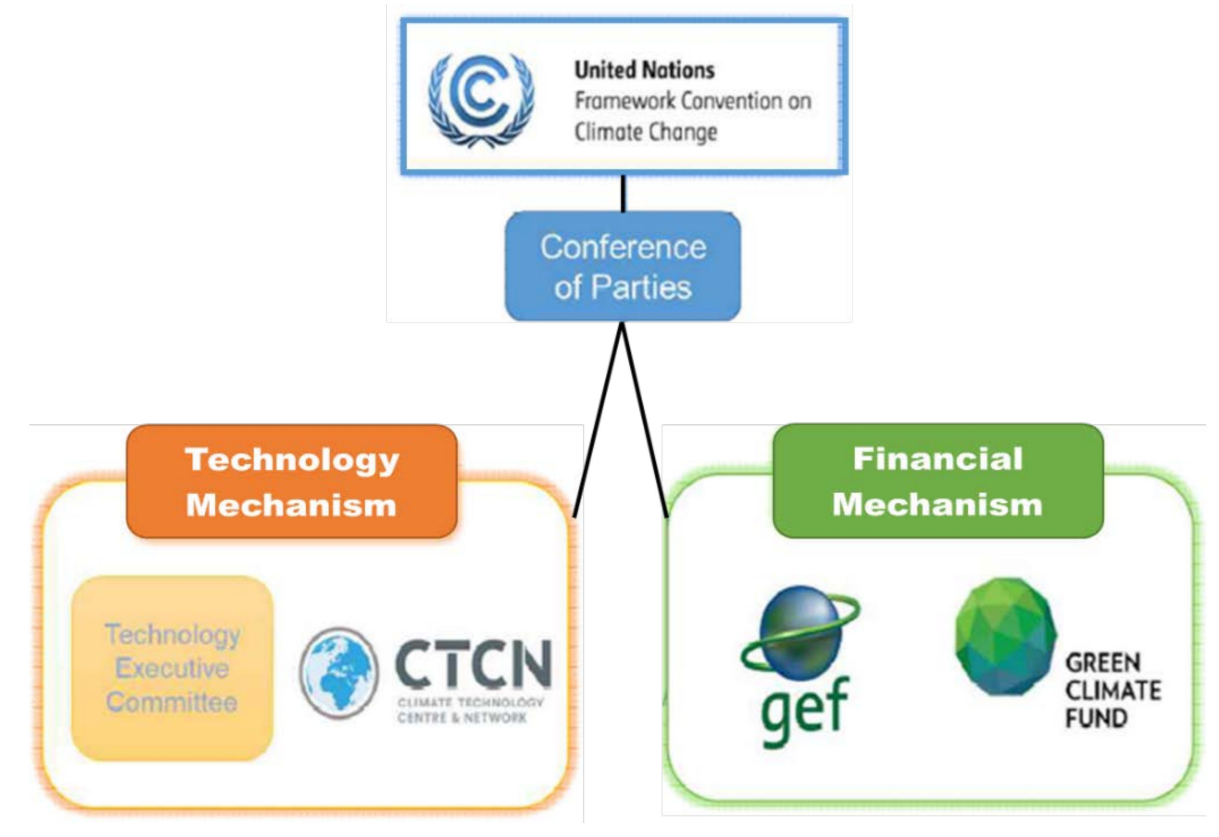

Figure 1. The United Nations Framework Convention on Climate Change (UNFCCC) Technology and Finance Mechanisms.

The UNFCCC Financial Mechanism includes the (1) Global Environment Facility (GEF) under the UNFCCC financial mechanism adopted in 1992, (2) Special Climate Change Fund (SCCF), (3) Least Developed Countries Fund (LDCF) and (4) Green Climate Fund (GCF), and (5) Adaptation Fund under Kyoto Protocol [12,15].

The most important aspect of cooperation under the technology mechanism is translating developing countries' technology requirements into practical and bankable projects. For this process, linkage with financial resources is key. There are two aspects of this linkage. First is the institutional aspect in which technical mechanisms are linked with financial mechanisms. In other words, the independent technical and financial mechanisms are linked in terms of operational processes, including the decision-making process. The second aspect is a linkage of the resources required for the implementation of technology projects. Secure, stable and sufficient financial resources are required to implement climate technology projects. Such resources can be obtained by linking with the UNFCCC financial mechanism, which is a source of public resources.

In this regard, the UNFCCC has pursued the institutional necessity of linking the technical and financial mechanisms. The 17th COP, held in 2011, requested that the GCF Board of Directors work with the Adaptation Committee, the Technology Executive Committee (TEC) and other relevant organizations under the Convention to define the linkage between GCF and these organizations ([16], decision 3/CP.17 para. 17). In addition, the 17th COP requested the TEC to formulate modalities that could be linked to relevant organizations both within and outside the Convention ([16], decision 4/CP.17 para. 6). Based on the Decision of the 18th COP (17], 3/CP.18 para. 17), it was 
agreed to specify the linkage between the technology and financial mechanisms at the 20th COP in 2015 [12,15].

\subsection{KTT in the Context of Global Climate Change}

Knowledge and Technology Transfer (KTT) has become a key focus of theoretical research as one of the most important means of increasing the competitiveness of private- and public-sector entities [1,17]. As pointed out by Farley and Sharer (2005) and Landry et al. (2005), technology can be understood as a key type of knowledge that is tangible, of specific use and impact, and able to make concrete changes to a technical environment. On the other hand, knowledge is intangible (implicitly stored people's brains), does not have a direct or concrete impact, and is more concerned with the use of theories and principles than of technological hardware $[18,19]$. Knowledge is a product of human reflection, experience, and resources [20,21].

The term Knowledge Transfer (KT) encompasses a broad range of activities to support mutually beneficial collaboration between the public, private, and voluntary sectors. It refers to the transfer of tangible and intellectual property, expertise, learning and skills, which are located in an individual or a collective, or embedded in a routine or process [17]. Researchers have varying concepts of KTT; Kogut and Zander [22] regard it as an important reason for the existence of enterprises; Szulanski [23] sees it within and between organizations across the boundaries of knowledge sharing; and Dosi [2], Szulanski [23] and Argote and Ingram [7] underline it as a process and activity through which an organization learns, applies, and recreates routines in a new setting.

In addition, Technology Transfer-regarded as a key source of knowledge transfer-has been defined in various ways by researchers including Megantz [24], Kingsley and Klein [25], Landry et al. [6], and so on. Friedmann and Silberman [26] and Roessner [27] define it as the movement of knowhow, skills, technical knowledge or technology from one organizational setting to another. Technology transfer is also understood to encompass the transfer of spinoffs, spill over, fusion and so on in the economy (among economists), focusing on a link between technology transfer, production, and commercialization $[1,28]$. In sum, the definition of technology transfer varies by research discipline and by purpose of the research. The types of technology transfer can be categorized into six sub-categories: assignment, cooperative research, licensing, spin-off, joint venture, and mergers and acquisitions [29].

This study notes that KTT encompasses a much broader range of activities, which is not limited to science and technology. In terms of activities, KTT can be carried out through people, publications, events, collaborative research, consultancy, licensing, and new business. Based on a survey on the KTT activities among Swiss science institutions by Arvantis et al. [1], KTT can be classified into five categories: informal informational activities, educational activities, research activities, consulting, and activities related to technical infrastructure. Furthermore, a survey by Vock et al. [30] and Thierstein et al. [31] on codified forms of KTT and the frequency of collaboration on R\&D, patents, and licences found that KTT is performed at various levels ranging from individual, intra-organizational, inter-organizational, and transnational.

\subsection{Analytical Framework of KTT for Korean Green Technology Projects}

This study found that the research on KTT takes two general perspectives: focus on the characteristics KTT (e.g., Kogut and Zander [22], Nonaka and Takeuchi [32]) and focus on the processes and interactions involved in KTT (e.g., Argote and Ingram [7], Arvantis et al. [1], Simonin [33], Szulanski [23,34]). In light of these perspectives, this paper tries to set up a comprehensive analytical framework to encompass the multiple features of KTT, including its rationale, process, objectives and results. In particular, this paper notes theoretical lessons from the research of Dolowitz [8] and Dolowitz and Marsh [35], who developed a policy transfer framework (regarded as a type of public KTT) that focuses on key questions of the transfer process, including: "why transfer", "who is involved in transfer", "what is transferred", "degree of transfer", "how transfer can lead to 
policy failure", and so on. Also, Tews et al. [36] examine variations in the external environments relating to policy transfer. Yi [37] highlights that the analytical framework of policy transfer consists of "independent variations" including reasons, processes, and features and "dependent variations" including results. Ha [38] outlines key factors in the three stages of policy transfer: the first stage of "idea adoption" includes context, motive, object, and degree of transfer; the second stage of "idea sharing" includes operation of a transfer network and actors' organization and activities; and the third stage of "idea institutionalization" includes legislation and the settlement of norms.

Utilizing the above results, this paper tries to create an analytical framework of KTT in relation to Korean green technology projects in the Philippines and the Dominican Republic carried out by the GTC-K, a governmental institute in the Republic of Korea. This framework may enable the analysis of KTT processes and also explain the rationale, activities and results of KTT.

As Figure 2 shows, the analytical framework sets the criteria of the rationale of KTT, as well as the objects and activities, and the degree and results of KTT. Through the rationale of knowledge transfer, this study explains the international environment and the motives for KTT in green technology projects in the Philippines and the Dominican Republic. Through the criteria of objects and activities of KTT as defined by Arvantis et al. [1], Thierstein et al. [31], and Vock et al. [30], it shows what is transferred and which actors and activities are involved in the KTT process, focusing on the four activity categories of:

1. "Informational contacts", including informal personal networks and phone and email communications, as well as formal conferences and workshops;

2. "Research activities", including research projects in collaboration and longer-term research contracts;

3. "Consulting", including expertise, reports, or consulting for bankable projects by the business sector; and

4. "Education and Training", including the participation of residents and local civil servants in projects

"Activities related to the technical facilities", one of five categories of the activities of KTT based on the Arvantis et al.'s [1] result, is not included into the element of the above criteria since much less importance was given to it through the survey of Arvantis et al. [1], and particularly it is not consistent in the context of the project cases that this study takes on (based on the focus group interview (FGI) results).

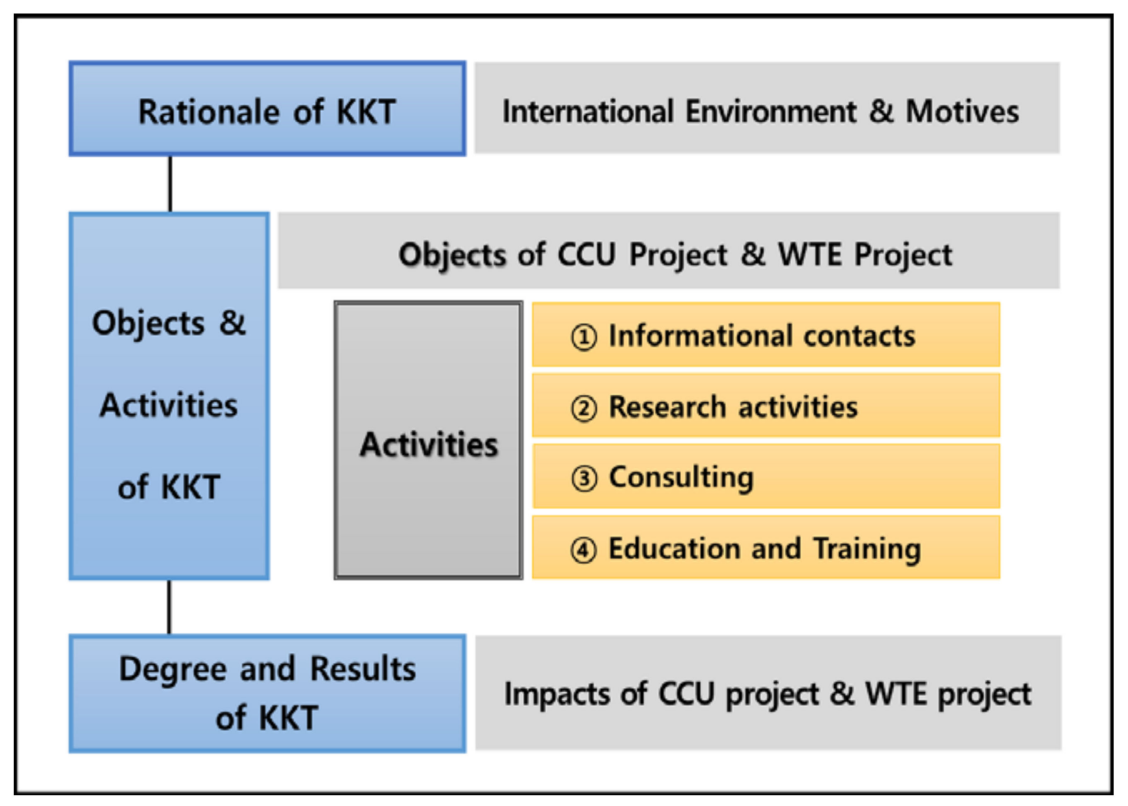

Figure 2. The UNFCCC analytical framework of Knowledge and Technology Transfer (KTT). 


\section{FINDINGS (1): Rationale of KTT}

\subsection{International Environment: Paris Agreement and GCF}

In 2015, at UNFCCC COP21, the Paris Agreement presented a new architecture on global governance on climate change from the year 2020. The Paris Agreement has structural features that differ from the Kyoto Protocol [14,16,39]. First, it consists of six elements: mitigation, adaptation, finance, technology transfer, capacity building, and transparency. Second, global collective efforts to respond to climate change are to be made by developed countries and by developing countries. Third, both private sector and government actors are encouraged to participate in international efforts under the Paris Agreement. Finally, unlike the Kyoto regime, the Paris Agreement adopts a bottom-up approach in which parties voluntarily commit to intended nationally determined contributions (INDCs). In this context, this study focuses on the framework of knowledge and technology transfer, which will be one of the most important means of implementation of the new climate change regime.

The UNFCCC recognizes the importance of new technologies for ensuring sustainable social and economic development while also ensuring greater energy efficiency and control greenhouse gas (GHG) emissions. Moreover, the Paris Agreement underlines that the global response to climate change shall be supported, including by the Technology Mechanism and, through financial means, by the Financial Mechanism of the Convention. The need for technology-related climate finance to achieve mitigation and adaptation goals has been recognized, and under the international environment, the role of GCF, has received much attention $[14,16,17]$. The GCF-located in Songdo, Incheon, Republic of Korea-was established at the 16th COP in Cancun in 2010 with the aim of raising $\$ 100$ billion by 2020 and generating long-term climate change fund of the same amount annually starting from 2020. At the 17th COP, the GCF was designated as the financial mechanism of the UNFCCC ([16], Decision 3/CP.17). Currently, the GCF has an investment execution plan of 10 trillion won, of which about 750 billion to 1 trillion won is set aside to be executed within 2015. The strategic focus of the GCF includes eight business sectors and four mitigation sectors comprising of low-carbon energy generation supply, low-carbon transportation and buildings [12,15]. As of the end of 2017, total 45 project/program proposals had been approved.

These financial resources for projects/programs in developing countries provided by GCF can only be accessed through Accredited Entities that are project/program implementing entities (IEs) that have gone through the GCF accreditation process. In addition, to ensure developing countries' ownership of climate change funding, countries' National Designated Authorities (NDAs) and Focal Points work between their country and the GCF on national priorities. Any proposal submitted to the GCF should be accompanied with a no objection letter form the NDA/FP.

\subsection{Motives: Domestic and Overseas Promotion of "Energy New Industry"}

The Korean government has recently increased its focus on green technology projects in order to increase its participation in global climate technology finance and projects/program implementation. The efforts of the Ministry of Science and ICT (MSIT) and the Ministry of Strategy and Finance (MSF) in this sphere to date include the establishment of energy new industry promotion programs, formulation of supporting policies and the creation of a platform for the development of energy new industry and related green technology infrastructure [40]. In particular, the MSF is the National Designated Authority (NDA) of the Republic of Korea and has sought robust interaction and cooperation with the GCF secretariat. In relation to preparing GCF projects, the MSF has implemented its GCF action plan task force (T/F) in cooperation with related ministries, including the MSIT. Meanwhile, in December 2016, the Korean Development Bank (KDB) was accredited as an IE (implementing entity) by the GCF, which became the first South Korean IE.

As Figure 3 shows, the Korean government has made efforts to build multilevel governance in relation to the linkage between climate technology and finance. In December 2015, the Korean 
government nominated the Ministry of Science and Future Planning (now restructured as the MSIT since 2017) as the country's National Designated Entity (NDE), the national focal point for the UNFCCC Technology Mechanism [41]. As an NDE, MSIT has sought to ensure that requests submitted to the CTCN reflect Korean national circumstances and priorities. In regard with the roles, MSIT works with the Ministry of Foreign Affairs (MOFA), receiving feedback on such international cooperation for climate change response [41,42].

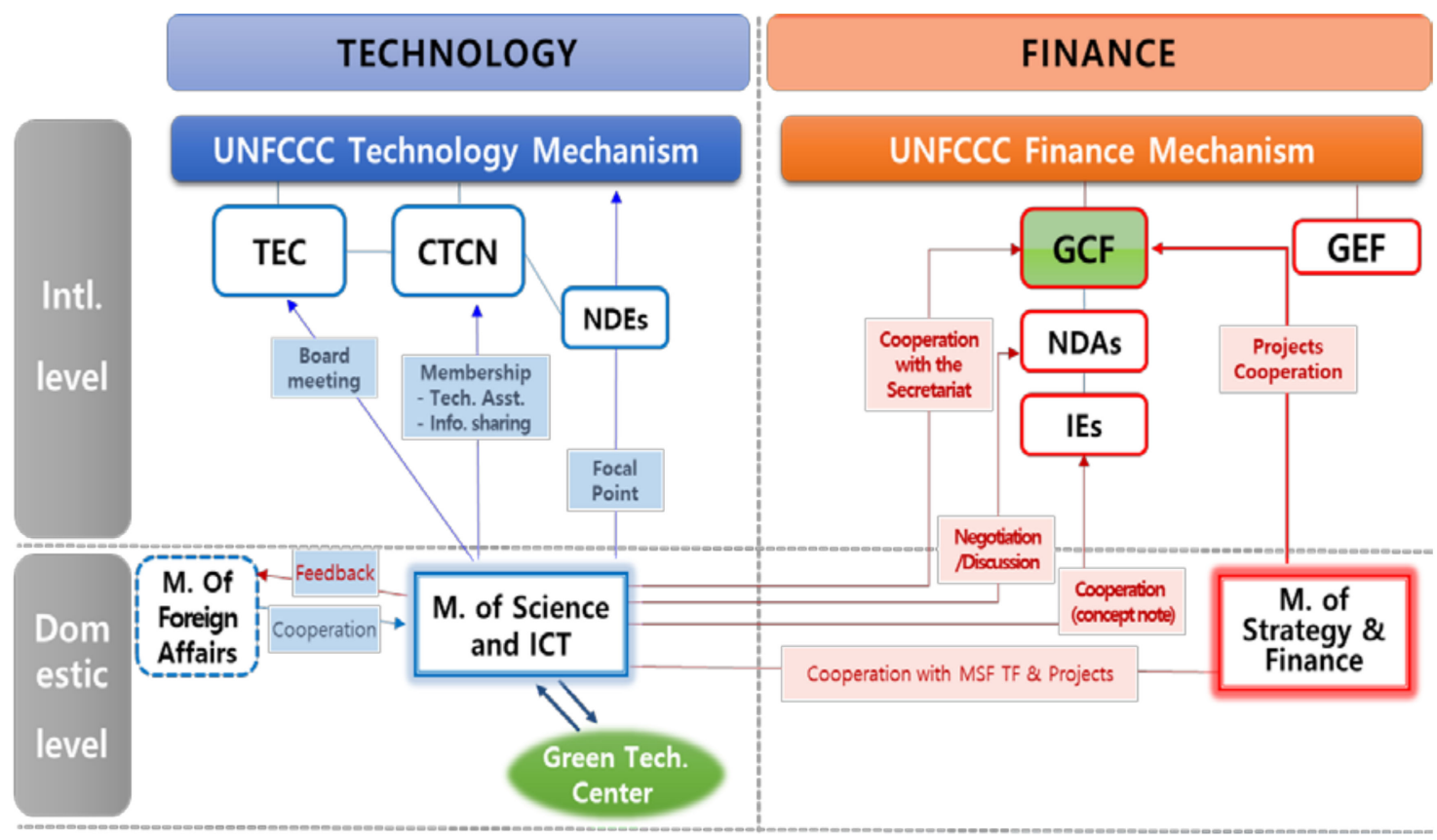

Figure 3. Korean multilevel governance with the linkage between climate technology and climate finance.

In particular, GTC-K, in robust cooperation with and guidance from MSIT, has worked to contribute to Korea's national development through research on climate change technology policy and international cooperation. The GTC-K became a member of the CTCN in May 2015 and has sought to play a role in information sharing and capacity building; providing technical assistance (TA) in response to country requests; and participating in outreach and networking activities [41,43]. The former chairperson of GTC-K has also been a TEC board member and built cooperation with developed and developing countries representatives on behalf of the region of Asia and Pacific (particularly South Korea). Furthermore, GTC-K has developed a model of Korean green technology transfer, focusing on energy independence in isolated regions for selected developing countries [40]. For example, the GTC-K presented Korean CCU technology in the Philippines and WTE technology in the Dominican Republic in order to share green technology best practices $[40,44]$. These efforts aim to contribute to the commercialization of these technologies through multilateral overseas cooperation, particularly in cooperation with the GCF and developing countries' NDAs [45].

As a result of these efforts, GTC-K and MSIT expect that such CCU and WTE projects could contribute to Korea's INDC to reduce GHG emissions by 37\% from the BAU level by 2030 [40]. In particular, the expected GHG emission reduction through the both projects can contribute to the reduction objective [40]. The model of green KTT to contribute to Korea's INDC, is characterized by "voluntary transfer driven by perceived necessity" $[8,35]$ according to the respondents' $(8,18,19,47)$ interview results. Based on the transfer continuum of Dolowitz and Marsh [8,35], the motives of KTT can be classified as "lesson drawing" (most voluntary, the left end of the continuum), "voluntary transfer driven by perceived necessity", "obligated transfer" (negotiated transfer), and "coercive transfer" (the right end of the continuum). 


\section{FINDINGS (2): Objects and Activities of KTT}

This study examines case studies of CCU and WTE projects carried out by GTC-K and its international and domestic partners from June of 2014 to May of 2016. The CCU project aimed to transfer technology and strengthen community capacity for its use on Bantayan Island, one of the three municipalities of the province of Cebu, Philippines. The WTE project sought to transfer technology to Santiago, the second largest city in the north of the Dominican Republic, while promoting inter-regional development cooperation. Figure 4 gives an overview of what technologies were transferred (object) and what activities ("informational contacts", "research activities", "consulting" and "education and training") were carried out with which actors.

\begin{tabular}{|c|c|c|c|c|c|c|}
\hline \multirow{3}{*}{$\begin{array}{c}\text { Abjects } \\
\text { Actors } \\
\text { Activities }\end{array}$} & \multicolumn{3}{|c|}{ CCU (PJ in Philippines) } & \multicolumn{3}{|c|}{ WTE (PJ in Dominican Rep.) } \\
\hline & \multirow{2}{*}{ GTC-K } & \multicolumn{2}{|c|}{ Partners } & \multirow{2}{*}{ GTC-K } & \multicolumn{2}{|c|}{ Partners } \\
\hline & & Intl. & Domestic & & Intl. & Domestic \\
\hline \multirow{4}{*}{$\begin{array}{l}\text { Informational } \\
\text { contacts }\end{array}$} & $\mathrm{O}$ & 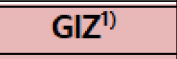 & & $\mathrm{O}$ & IDB $^{4}$ & \\
\hline & $\mathrm{O}$ & LGU $^{2)}$ & & $\mathrm{O}$ & CNCCMDL $^{5)}$ & \\
\hline & O & & KIGAM $^{3)}$ & $\mathrm{O}$ & & KIER $^{6)}$ \\
\hline & $\mathrm{O}$ & & Corp. partner & $\mathrm{O}$ & & Corp. partner \\
\hline \multirow{4}{*}{$\begin{array}{l}\text { Research } \\
\text { activities }\end{array}$} & 0 & GIZ & & \multirow{2}{*}{$\mathrm{O}$} & \multirow{2}{*}{$\|\left. B\right|^{7}$} & \\
\hline & $\mathrm{O}$ & Unv.of SC & & & & \\
\hline & $\mathrm{O}$ & & KIGAM & $\mathrm{O}$ & & KIER \\
\hline & $\mathrm{O}$ & & Seoul Inst. & $\mathrm{O}$ & & Corp. partner \\
\hline \multirow{4}{*}{ Consulting } & \multirow{2}{*}{$\mathrm{O}$} & \multirow{2}{*}{ GIZ } & & $\mathrm{O}$ & IDB & \\
\hline & & & & $\mathrm{O}$ & CNCCMDL & \\
\hline & 0 & & KIGAM & $\mathrm{O}$ & & KIER \\
\hline & O & & Corp. partner & $\mathrm{O}$ & & Consulting corp. \\
\hline \multirow{3}{*}{$\begin{array}{l}\text { Education } \\
\text { \& Training }\end{array}$} & 0 & LGU & & \multirow{3}{*}{$\mathrm{O}$} & & KIER \\
\hline & 0 & & KIGAM & & & \multirow{2}{*}{ KIST } \\
\hline & $\mathrm{O}$ & & Corp. partner & & & \\
\hline
\end{tabular}

Figure 4. Overview of the objects, actors, and activities of KTT in the case projects. ${ }^{(1)}$ GIZ: German Federal Enterprise for Intl. Co.; ${ }^{(2)}$ LGU: Local Gov. Unit (Cebu); ${ }^{(3)}$ KIGAM: Korea Institute of Geoscience \& Mineral Resources; ${ }^{(4)}$ IDB: Inter-American Dev. Bank; (5) CNCCMDL: Natl. Council on Climate Change \& Clean Dev. Mechanism; ${ }^{(6)}$ KIER: Korea Institute of Energy Research; ${ }^{(7)}$ IIBI: Institute of Innovation for Biotech. \& Industry; ${ }^{(8)}$ KIST: Korea Institute of Science \& Tech.

\subsection{Objects of the CCU Project (Philippines) and the WTE Project (Dominican Republic)}

The technology to be transferred through the project on Bantayan was carbon dioxide capture and utilization technology using municipal waste, carbon dioxide and limestone. This technology is designed to recover useful resources such as metals, plastics, paper, and so on, and to treat flammable and non-combustible municipal wastes. It processes limestone by using the heat generated in the treatment and treats the processed limestone as a soil stabilizer. Through this CCU technology, the project sought to implement the recycling of municipal waste and promote a model for a sustainable circular economy on Bantayan Island [40-42].

The Santiago project focused on the production of renewable energy using high-energy waste from the city's Rafey landfill in order to generate a power supply that could foster the commercialization of nearby communities and urban areas $[40,41,46]$. The target technology uses solid, liquid, and gaseous 
fuels produced by processing flammable wastes and uses energy generated by their combustion or conversion.

\subsection{Activity (1): Informational Contacts}

In terms of the formal and informal informational contact activities including workshops/conferences, as well as a forum in the case of the CCU projects, GTC-K initiated activities with staff of the Philippine national government and the Cebu local government and the German Federal Enterprise for International Cooperation (GIZ) through a conference on the green technology and industry held in Seoul, Korea in May 2014 [17]. GTC-K sought to maintain this connection for the development of a joint waste disposal and waste to energy project by holding workshops on Bantayan Island in June and September 2014 [18,44]. After a further practical workshop in Cebu in March 2015, GTC-K and the Korean partner organizations, KIGAM (Korea Institute of Geoscience and Mineral Resources) and the corporate partner visited the provisional project sites for a first field survey on Bantayan in June 2015 and hosted a workshop to discuss green technology transfer with local government officials and the GIZ. Finally, in September 2015, a performance workshop was held with Bantayan stakeholders [43-45].

As Figure 5 shows below, the informal phone and e-mail contact activities through the CCU project in Bantayan were carried out about eight to 16 times a month during the project period, between GTC-K, GIZ and the Cebu local government, as well as between GTC-K and KIGAM and the corporate partner. In addition, the meetings to discuss administrative, business, and research issues took place from one to three times a month during the project period between GTC-K and KIGAM and the corporate partner $[40,43,47]$.

\begin{tabular}{|c|c|c|c|c|c|c|c|c|}
\hline \multirow{4}{*}{$\begin{array}{l}\text { Informational } \\
\text { contacts }\end{array}$} & \multicolumn{4}{|c|}{ CCU project (Philippines) } & \multicolumn{4}{|c|}{ WTE project (Dominican Rep.) } \\
\hline & \multirow{3}{*}{ No. of times } & \multicolumn{3}{|c|}{ Actors } & \multirow{3}{*}{ No. of times } & \multicolumn{3}{|c|}{ Actors } \\
\hline & & \multirow{5}{*}{$\begin{array}{l}\text { G } \\
T \\
\text { C }\end{array}$} & $\mathrm{GIZ}$ & KGAM & & \multirow{5}{*}{$\begin{array}{l}\mathbf{G} \\
\mathbf{T} \\
\mathrm{C}\end{array}$} & IDB & KIER \\
\hline & & & LGU & $\begin{array}{c}\text { corp. } \\
\text { partner }\end{array}$ & & & $\begin{array}{l}\text { CNCC } \\
\text { MDL }\end{array}$ & $\begin{array}{c}\text { corp } \\
\text { partner }\end{array}$ \\
\hline $\begin{array}{l}\text { workshops } \\
\& \text { forum }\end{array}$ & 6 (5 overseas) & & ○ & 0 & 9 (8 overseas) & & ○ & $\bullet$ \\
\hline $\begin{array}{l}\text { phone \& } \\
\text { E-mail }\end{array}$ & 8-15 (month) & & ○ & - & 8-25 (month) & & - & - \\
\hline meetings & $1-3$ (month) & & & - & $1-8$ (month) & & ○ & ○ \\
\hline
\end{tabular}

Figure 5. Informational contact activities in the carbon capture and utilization (CCU) and waste-to-energy (WTE) projects.

For the WTE project in the Dominican Republic, GTC-K staff first participated in the Caribbean Renewable Energy Forum held in Miami, USA, in October 2014 to connect with and develop cooperation with IDB (Inter-American Development Bank) and the Dominican Republic government [18]. Following the forum, GTC-K staff visited Santo Domingo to meet representatives of various public bodies including the CNCCMDL (Climate Change and Clean Development Mechanism National Committee), the Ministry of Energy and Mining, and IIBI (Institute of Innovation for Biotechnology and Industrial Innovation) [44]. The parties discussed the development of waste and renewable energy technology projects. In March 2015, GTC-K hosted a joint Knowledge Sharing workshop in Seoul, with officials from the Dominican government and IDB [40]. GTC-K staff then visited the Dominican Republic again in June 2015 to conduct a field survey and for further detailed discussions on a GCF-funded project with the Dominican Republic's NDA to the GCF, the Ministry of 
Environment and Resources, as well as the CNCCMDL [40]. GTC-K staff also discussed the project with the National Energy Commission. In total, four meetings were held with these governmental bodies [40].

Informal phone and e-mail contact activities for the WTE project were carried out about eight to 25 times a month during the project period between the GTC-K and CNCCMDL and IDB, and between GTC-K, the corporate partner and KIER (Korea Institute of Energy Research) [40,41]. In addition, meetings to discuss administrative, business, and research issues were held between one and eight times a month during the project period, mainly between GTC-K, the corporate partner and KIER, as well as between GTC-K and IDB [42,45]. For example, GTC-K staff visited the IDB headquarters in Washington, DC, USA, in September 2015 to meet the IDB staff in charge of the organization's duties as a GCF IE to inform them of the WTE project arrangements and to discuss key preparations for making a GCF funding proposal $[41,42,47]$.

\subsection{Activity (2): Research Activities}

For the CCU project, the GTC-K attempted to carry out the research in collaboration with GIZ, University of San Carlos, KIGAM, the Seoul Institute, and the corporate partner. Under the GIZ's ProGed initiative (Promotion of Green Economic Development) that aims to propel small and medium enterprises and government institutions relevant to economic development to increasingly implement inclusive, environment-friendly, and climate-smart strategies and measures, GTC-K and GIZ's branch in Philippines started cooperation in June 2014 [41,48]. In April 2015, GTC-K and KIGAM signed an MOU on the transfer and expansion of overseas technology research [40]. In relation to the environmental, economic and social feasibility study(FS) of CCU technology transfer, from March to August 2015, GTC-K, KIGAM, and the corporate partner visited the sites including waste landfills (in Santafe city and Bantayan city) and limestone production areas on Bantayan Island [40,41]. They then conducted an analysis of waste composition and related economic and social impact. The FS was conducted and completed based on a joint-research contract with GTC-K and KIGAM [40,42,47]. In addition, GTC-K commissioned a five-month research contract to the University of San Carlos in Cebu to survey local data and local community circumstances, and also to the Seoul Institute (contract of four months) to develop participatory tools for community capacity-building in managing waste recycling and disposal in the Bantayan Island [41,43].

In terms of the WTE project, GTC-K signed an agreement with IDB in September 2014 to increase bilateral cooperation for green technology-based economic growth in Latin America and the Caribbean, focusing on increasing public-private cooperation related to green technology research, such as waste energy and renewable energy [40]. After a joint workshop in March 2015, GTC-K, KIER, and the corporate partner prepared a feasibility study (FS) on WTE technology and visited the Dominican Republic in June 2015 to carry out the FS for the analysis of the waste disposal system, power generation conditions, and the environmental and social context of the Duquesay and Rafey landfills in Santo Domingo and Santiago cities [40,41]. The FS was conducted and completed in September 2015, through a joint-research contract between GTC-K and KIER and an eight-month commissioned research contract with GTC-K and the corporate partner [40,42]. In addition, GTC-K commissioned a three-month research contract for analysing a waste composition of the landfills with IIBI (Institute of Innovation for Biotechnology \& Industry) in the Dominican Republic in July 2015 [41,42].

\subsection{Activity (3): Consulting}

With regard to consulting for bankable projects, GTC-K made various efforts for the CCU project, particularly for a GCF project funding proposal. GTC-K sought to build a connection with IEs of the GCF, such as ADB (Asian Development Bank) by arranging meetings at ADB headquarters in Manila [40]. GTC-K also assisted GIZ staff in Cebu to create a solid network with the Philippines' NDA to the GCF, the Climate Change Commission $[40,45]$. For example, GTC-K communicated the 
governance structure and funding process of the GCF to GIZ staff, KIGAM and the corporate partner. and consulted on how to match the CCU project with GCF eligibility criteria [41,42].

For the WTE project, the GTC-K's efforts were more concrete. In cooperation with IDB, which is an IE to the GCF, GTC-K developed a GCF funding proposal by providing proposal contents and holding several on- and offline discussions with Dominican and Korean partner organizations such as CNCCMDL and KIER [40,41]. Through a consulting contract, GTC-K and KPMG analysed the evaluation criteria of GCF funding projects and created a guideline to assist Dominican Republic government actors, including the NDA, and IDB staff to manage a pipeline of bankable projects [42].

\subsection{Activity (4): Education and Training}

In relation to community participation and training for the CCU project, GTC-K suggested the development of a manual on waste treatment technologies and practices for Bantayan stakeholders including residents, civil servants, and NGO staff $[42,43,47]$. Through several training and research workshops in Bantayan, Korean experts form GTC-K, KIGAM, and the corporate partner communicated on community needs for an effective waste management plan to improve the conditions for residents as well as to support the expansion of tourism, given the serious problems over waste disposal. These representatives informed local stakeholders on how to develop their capacity to create a manual, plan, and policy tools on waste management for their community $[40,42]$.

With regard to the WTE project in the Dominican Republic, the education activities took place during the three-day joint workshop [40]. Nine staff from the CNCCMDL, Ministry of Energy and Mining, and the IIBI visited the Green Technology Research Center of Korea Institute of Science and Technology, in Seoul, and KIER, in Daejeon, for training on Korean green technology and the expected effects of such technologies if transferred to the Dominican Republic [47]. Korean experts and Dominican participants discussed a variety of new renewable energy source and application technologies $[40,43]$.

\section{Policy Implications: Degree and Results of KTT}

Although the technologies were ultimately not implemented, meaningful results were produced in both the Bantayan CCU project and the Santiago WTE project. For example, based on the FS results and KTT activities including research and information sharing, GTC-K produced a development plan for a CCU waste treatment model using co-incinerator technology that treats closed-shell and limestone for soil restoration, fertilizer, feedstuff and wastewater treatment [44]. The plan was informed by the identification of the waste composition and by analysing the treatment capacity of 15 ton/day nonorganic waste out of total 37 ton/day (13,464 tons annually) in landfills on Bantayan Island [41,42].

Furthermore, through the WTE project FS results and the GCF funding proposal, GTC-K provided an integrated waste management plan for Rafey landfill in Santiago, which could potentially be applied to 350 other landfills in the country [41,47]. The power generation capacity installed in this site would be up to $10 \mathrm{MW}$, and it is expected to have at least average 60,342 MWh generation capacity, annually. This would enhance access to low-carbon energy for 11,672 households in Rafey per year, and 32 households per day [43,47].

However, after concluding the FS results and GCF funding proposal, GTC-K and MSIT withdrew from both the CCU and WTE projects without entering the project initiation phase. In the case of the CCU project, GTC-K concluded that the amount inorganic waste in the waste mix was too high for successful commercialization [42]. Therefore, the project should be developed as a public recycling initiative rather than as a profit-seeking energy generation endeavor [45]. In the case of the WTE project, ownership issues at the Rafey landfill project site were an insurmountable barrier to project initiation. This landfill was originally publicly-owned by the Santiago City government. However, the land ownership was transferred to the private sector during the period of GTC-K and the Dominican government's KTT activities [42]. During this process, the mayor of Santiago, who was from the 
opposition rather than the ruling party, was not committed to communicating and coordinating with the Dominican national government or the CNCCMDL in relation to the WTE project $[43,47]$.

In conclusion, this paper revealed the findings through the "word cloud" from the interviews (see Figure 6) - the clouds give greater prominence (size) to words that appear more frequently from the interviews and believes that the results of KTT in the CCU and WTE projects show an aspect of "uninformed transfer" $[8,9]$. Dolowitz and Marsh's $[8,9]$ other arguments on the degree and result of (policy) transfer are "incomplete transfer" indicating that the transfer without a critical factor for success is likely to lead to a failure and "inappropriate transfer" failing to take into account differences in economic, social, political, and ideological contexts between the transferring countries and transferred countries. The "uninformed transfer" reflects that transfer degree and results of KTT efforts were challenged by a lack of information, such as on the object technology and management methods as well as on situational factors. This includes, for example, the cooperation and commitment problems between the national and local governments, as identified by several interviewees $(1,2,4$, 6, and 7).
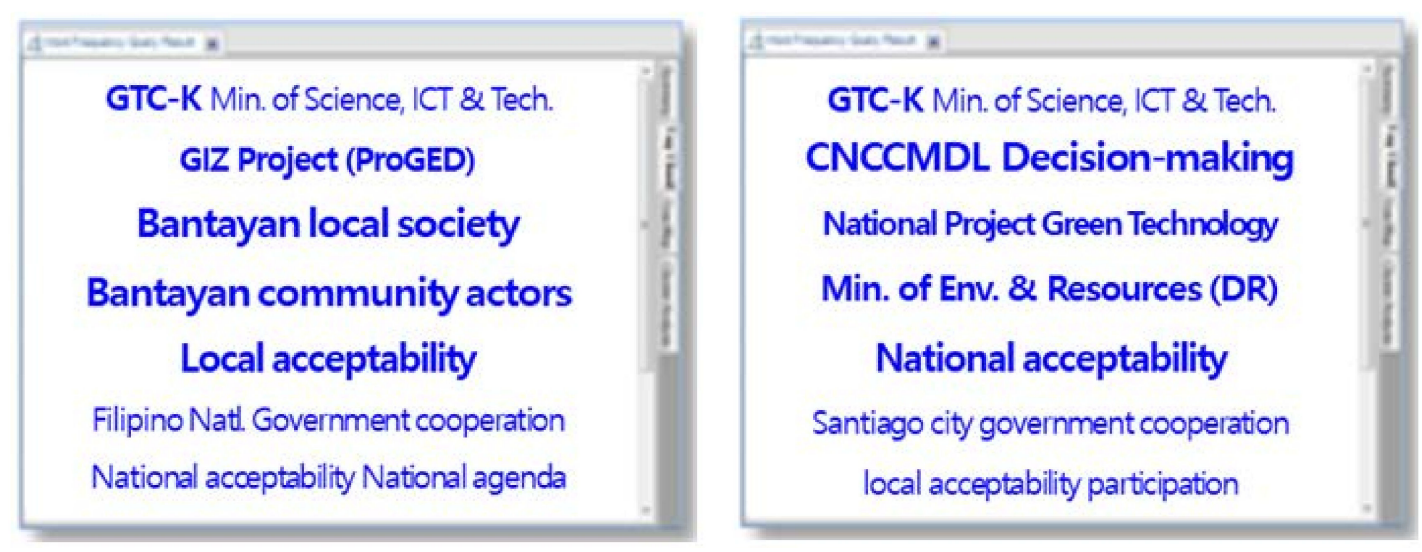

Figure 6. The "word cloud" from focus group interviews (FGI) on the result of the both cases of KTT.

With regard to the results of "uninformed transfer", this study notes the importance of the concept of "social acceptability" of renewable energy projects $[15,49,50]$. As many studies note $[15,49,51,52]$ the context of acceptability differs for each recipient. It should be understood that local community acceptability of renewable energy project facilities often differs from national actors' acceptability. Considering the CCU and WTE projects, the social gap, defined as the gap between national (social) acceptability and local community acceptability [53], emerged as important obstacles.

Figure 6 shows "word clouds" (NVIVO program) that highlight words that appeared more frequently in the interviews. These results show that the CCU project received much attention from the local Bantayan community but not from the national government. On the other hand, the WTE project attracted a great deal of attention from the Dominican national government but did not attract significant cooperation from the government of Santiago City, where the WTE facility would be installed. In short, it is necessary to better understand that the social acceptability of renewable energy projects. This concept could be divided into three areas: national, local, and market acceptability, given that the recipients differ according to the KTT context. At the same time, it is important to avoid misunderstanding national acceptability as local acceptability or vice versa, and to closely examine the dynamics between the receptive domains (areas) and the related subjects (stakeholders). In particular, to tackle the problems of social gap found in the CCU and WTE projects, this study suggests the necessity of participatory governance mechanism between public, private, and voluntary sectors. For this, it is required to emphasize the participation of citizens and cooperation between (private or/and voluntary) organizations and government entities. Both the CCU and WTE projects should be approached by intensive bottom-up methodologies from the local communities and the recipient 
country governments rather than by top-down methodologies from the donor country (Korean) government and organizations (GTC-K). In other words, the main goals of the overseas renewal energy projects in the context of KTT are required to encourage local residents and recipient country governments to have ownership of the solutions.

Acknowledgments: This research was supported by the research program of "Global Cooperation Case Studies on Green Technology Convergence for Climate Change Responses" (F15330, F16330) of the Green Technology Center-Korea (GTC-K).

Author Contributions: Taewook Huh, the first and the corresponding author designed the very structure of the article and completed the writing-up under the cooperation with the co-author. Hyung-Ju Kim as the co-author contributed in completing the writing-up and revising the article as a whole.

Conflicts of Interest: The authors declare no conflict of interest.

\section{References}

1. Arvanitis, S.; Kubli, U.; Woerter, M. University-industry knowledge and technology transfer in Switzerland: What university scientists think about co-operation with private enterprises? Res. Policy 2008, 37, 1865-1883.

2. Dosi, G. Technological paradigms and technological trajectories. Res. Policy 1982, 11, 147-162.

3. Hansen, M.T. The search-transfer problem: The role of weak ties in sharing knowledge across organizational subunits. Adm. Sci. Q. 1999, 44, 82-111.

4. Schoen, A.; Potterie, B.P.; Henkel, J. Governance typology of universities' technology transfer processes. Technol. Transf. 2014, 39, 435-453.

5. Farley, T.L.; Sharer, M. Technology Transfer and Innovation: Reexamining and Broadening the Perspective of the Transfer Discoveries Resulting from Government-Sponsored Research. Comp. Technol. Transf. Soc. 2005, 3, 109-128.

6. Landry, R.; Amara, N.; Ouimet, M. Determinants of Knowledge Transfer: Evidence from Canadian University Researchers in Natural Sciences and Engineering. J. Technol. Transf. 2007, 32, 561-592.

7. Argote, L.; Ingram, P. Knowledge transfer: A basis for competitive advantage in firms. Organ. Behav. Hum. Decis. Process. 2000, 82, 150-169.

8. Dolowitz, D. British Employment Policy in the 1980s: Learning from the American Experience. Governance $1997,10,23-42$.

9. Green Technology Center (GTC). Study for Building a Global Green Energy Community; GTC: Seoul, Korea, 2014.

10. Technology Executive Committee (TEC). Technology and the UNFCCC, Building the Foundation for Sustainable Development; United Nations Framework Convention on Climate Change: New York, NY, USA, 2016.

11. Standing Committee on Finance (SCF). Biennial Assessment and Overview of Climate Finance; SCF: Bradenton, FL, USA, 2014.

12. UNFCCC. Technology Mechanism; UNFCCC: New York, NY, USA, 2015.

13. UNFCCC. Linkages between the Technology Mechanism and the Financial Mechanism of the Convention; UNFCCC: New York, NY, USA, 2015.

14. UNFCCC. Annex Key Messages to Be Delivered to the Conference of the Parties at Its Twenty-First Session; UNFCCC: New York, NY, USA, 2015.

15. UNFCCC. Joint Annual Report of the Technology Executive Committee and the Climate Technology Centre and Network; UNFCCC: New York, NY, USA, 2015.

16. UNFCCC. Report of the Conference of the Parties on Its Seventeenth Session (28 November to 11 December 2011); UNFCCC: New York, NY, USA, 2011.

17. Bang, H.; Wang, F.; Lu, J. Knowledge Transfer Between MNCs Headquarter and Overseas Subsidiaries -Through Reducing Two Gap. In Proceedings of the Korea Academy of International Management, Autumn Conference, Seoul, Korea, 7-11 August 2015.

18. Centobelli, P.; Cerchione, R.; Esposito, E. Knowledge Management in Startups: Systematic Literature Review and Future Research Agenda. Sustainability 2017, 9, 36.

19. Yang, J.; Yuan, M.; Yigitcanlar, T.; Newman, P.; Schultmann, F. Managing Knowledge to Promote Sustainability in Australian Transport Infrastructure Projects. Sustainability 2015, 7, 8132-8150.

20. Lin, Y.C.; Ha, N.H. The Framework for KM Implementation in Product and Service Oriented SMEs: Evidence from Field Studies in Taiwan. Sustainability 2015, 7, 2980-3000. 
21. Wang, P.I.D.; Zhu, F.; Song, H.; Hou, J.; Zhang, J. Visualizing the Academic Discipline of Knowledge Management. Sustainability 2018, 10, 682.

22. Kogut, B.; Zander, U. Knowledge of the firm and the evolutionary theory of the multinational corporation. J. Int. Bus. Stud. 2003, 34, 516-529.

23. Szulanski, G. Exploring internal stickiness: Impediments to the transfer of best practice within the firm. Strateg. Manag. J. 1996, 17, 27-43.

24. Megantz, R.C. Technology Management: Developing and Implementing Effective Licensing Programs; John Wiley and Sons: New York, NY, USA, 2002.

25. Kingsley, G.; Klein, H. Inter-firm collaboration as a modernization strategy: A survey of case studies. J. Technol. Trans. 1998, 23, 65-74.

26. Friedman, J.; Silberman, J. University technology transfer: Do incentives, management, and location matter? J. Technol. Transf. 2003, 28, 17-30.

27. Roessner, J.D. Technology transfer. In Science and Technology Policy in the US, A Time of Change; Hill, C., Ed.; Longman: London, UK, 2000.

28. UNEP Riso Centre on Energy, Climate and Sustainable Development. Technologies for Adaptation: Perspectives and Practical Experiences; UNEP: Nairobi, Kenya, 2011.

29. Eom, S. Eco Energy Self Sufficient Island Project. The Korean Society for New and Renewable Energy. In Proceedings of the Spring Conference, Busan, Korea, 3-5 June 2015.

30. Vock, P.; Sultanian, E.; Hinrichs, U. Technologietransferaktivitäten 2002-Umfrage bei Hochschulen und öffentlich finanzierten Forschungsorganisationen, Zentrum für Wissenschafts- und Technologiestudien; CEST 2004/3; Haupt Verlag: Bern, Switzerland, 2004.

31. Thierstein, A.; Wilhelm, B.E.; Behrendt, H. Gründerzeit. Unternehmensgründungen von Absolventen der Ostschweizer Hochschulen, Schriftenreihe des Instituts für Öffentliche Dienstleistungen und Tourismus der Universität St. Gallen, Beiträge zur Regionalwirtschaft; Haupt Verlag: Bern, Switzerland, 2002.

32. Nonaka, I.; Takeuchi, H. The Knowledge Creation Company: How Japanese Create the Dynamics of Innovation; Oxford University Press: Oxford, UK, 1995.

33. Simonin, B.L. Ambiguity and the process of knowledge transfer in strategic alliances. Strateg. Manag. J. 1999, 20, 595-623.

34. Szulanski, G. The process of knowledge transfer: A diachronic analysis of stickiness. Organ. Behav. Hum. Decis. Process. 2000, 82, 9-27.

35. Dolowitz, D.; Marsh, D. Learning From Abroad: The Role of Policy Transfer in Contemporary Policy Making. Governance 2000, 13, 5-24.

36. Tews, K.; Busch, P.O.; Jorgens, H. The Diffusion of New Environmental Policy Instruments. Eur. J. Polit. Res. 2003, 42, 569-600.

37. Yi, C. Policy Transfer in Policy Making Process of Science and Technology: The Korean Case of the Adoption of Research Council System. Soc. Sci. Res. Rev. 2010, 26, 27-54.

38. Ha, D. Policy Transfer and Spread: The Case of Manifesto Movement in Japan. Korean Policy Stud. Rev. 2010, 19, 245-273.

39. UNFCCC. Report of the Conference of the Parties on Its Eighteenth Session (26 November to 8 December 2012); UNFCCC: New York, NY, USA, 2013.

40. Green Technology Center (GTC). Study on the Establishment of Green Technology Cooperative System in Developing Countries in Relation to International Organizations' Activities; GTC: Seoul, Korea, 2015.

41. Green Technology Center (GTC). Internal Document; GTC: Seoul, Korea, 2015.

42. Green Technology Center (GTC). Internal Document; GTC: Seoul, Korea, 2016b.

43. Green Technology Center (GTC). Internal Document; GTC: Seoul, Korea, 2016d.

44. Green Technology Center (GTC). Study on the Integrative Planning of Global Climate Change: The Cases of Green Islands; GTC: Seoul, Korea, 2015.

45. Green Technology Center (GTC). Exploring Opportunities for Climate Technology Financing: Focus on the Green Climate Fund; GTC: Seoul, Korea, 2016.

46. Devine-Wright, P. Beyond NIMBYism: Towards an Integrated Framework for Understanding Public Perceptions of Wind Energy. Wind Energy 2005, 8, 125-139.

47. Green Technology Center (GTC). Internal Document; GTC: Seoul, Korea, 2016c. 
48. Green Technology Center (GTC). Global Strategies of Global Diffusion of Microgrid. In Proceedings of the Green Technology Center Forum of Energy Independent Microgrid Diffusion Strategy, Seoul, Korea, 10 December 2015.

49. Pasqualetti, M.J. Living with wind power in a hostile landscape. In Wind Power in View: Energy Landscapes in a Crowded World; Pasqualetti, M.J., Gipe, P., Righter, R.W., Eds.; Academic Press: San Diego, CA, USA, 2002.

50. Wüstenhagen, R.; Wolsink, M.; Bürer, M. Social acceptance of renewable energy innovation: An introduction to the concept. Energy Policy 2007, 35, 2683-2691.

51. Wolsink, M. Wind power implementation: The nature of public attitudes: Equity and fairness instead of backyard motives. Renew. Sustain. Energy Rev. 2007, 11, 1188-1207.

52. Wolsink, M. Planning of renewable schemes: Deliberative and fair decision-making on landscape issues instead of reproachful accusations of non-nation. Energy Policy 2007, 35, 2692-2704.

53. Bell, D.; Gray, T.; Haggett, C. The "Social Gap" in Wind Farm Siting Decisions: Explanations and Policy Responses. Environ. Polities 2005, 14, 460-477.

(C) 2018 by the authors. Licensee MDPI, Basel, Switzerland. This article is an open access article distributed under the terms and conditions of the Creative Commons Attribution (CC BY) license (http:/ / creativecommons.org/licenses/by/4.0/). 